原著

\title{
産婦の不安を軽減するための 看護の方法に関する研究
}

一自律訓練法によるRelaxation 効果からみて一

森恵 美*・前 原 澄 子**

\section{Research on the Nursing Care to Reduce the Anxiety of Women During Labor and Delivery}

\section{-From the Relaxation Effect by Autogenic Training-}

\author{
Emi Mori* - Sumiko Maehara** \\ *The Japanese Red Cross College of Nursing \\ **Chiba University, School of Nursing
}

\begin{abstract}
To reduce the anxiety of the women during labor and delivery, Autogenic Training was given as a relaxation method, one of the structural factors of childbirth prepared programs. The research was pursed with the purpose of investigating the effects. State anxiety (STAI), labor pain, blood pressure, pulse, neuromuscle control, and Lamaze method evaluation were measured and evaluated for the following three groups;

Autogenic Training Completes(11)

Autogenic Training Non-Completes $(21)$

Autogenic Training Non-Recipients (12)

As a result, Autogenic Training Completes showed distinctive differences from the other two groups at the transition period at the end of the 1st stage in terms of state anxiety, the sensory scores of labor pain, neuromuscle control, and Lamaze method evaluation. The mean values of blood pressure and pulse in this group were lower than those in the other two groups whithout significant difference. In short, the study has shown that giving relaxation method before childbirth to reduce anxiety and labor pain is effective in achieving those goals.
\end{abstract}

要旨

産婦の不安の軽減のために, 分婏準備教育のプログラムの 1 構成要素であるRelaxation

*日本赤十字看護大学

$* *$ 千葉大学看護学部

受理 : 平成 3 年 4 月 25 日

Accepted: April 25, 1991 
の技法に関して，自律訓練法を教授することにより，その効果を検証することを目的とし て研究を行った.

自律訓練法習得群(11名), 自律訓練法未習得群(21名), 自律訓練法未訓練群(12名)の 3 群について, 分婏経過に沿って, 状態不安・産痛・血圧・脈拍数・神経筋コントロール力・ ラマーズ法評価を測定し，評価した．その結果，自律訓練法習得群と他の 2 群との間には， 分婏第 1 期の終わりである極期において, 状態不安・産痛の感覚的評価指数・神経筋コン トロール力判定結果・ラマーズ法評価得点に, 明らかな差がみられた. 陣痛間歇期の血圧・ 脈拍数に扔いては, 自律訓練法習得群の平均值が他の 2 群より低かったが, 有意差はなかっ た。

以上により, 産婦の不安の軽減や産痛の緩和のために, 分婏前からRelaxationの技法 を教授することにより，産婦の不安の軽減や産痛の緩和に有効であることが明らかになっ た。

\section{I.はじめに}

Benson ら ${ }^{1)}$ は自律訓練法 (Das Autogene Training, ATと略す)や漸進的笳弛緩法などの Relaxationの技法によるRelaxation 中に, 弛 緩反応 (Relaxation response: 呼吸数 - 心拍数 の減少之, 筋緊張の減少にともなら生理学的変 化を含めたすべての反応)が起こることを発見 した. 反対に, 不安や恐怖等の情動は, 交感神 経を興奮させ，心臓血管系の活動を刺激し，心 拍数が増加すること ${ }^{2)}$ や, 血圧值が上昇するこ と 3)が報告されている，以上より，Relaxation の技法によって達成される Relaxation は, 弛 緩反応を起こし，自律神経系効果において，不 安・恐怖の情動反応と拮抗的な機能をもってい ること4)がより明白となった。

$\mathrm{AT}^{5)}$ は, Relaxationの技法の一つで, 段階 的に練習を重ねることにより，習熟することが できる. 現在, ATは心身症の治療法の一つと して広く用いられており6)，その習熟により治 療効果があったこと7)や，心身症改善群では初 診時の高い状態不安が有意に減少したこと ${ }^{8)}$ が 報告されている.

一方, 分婏進行に伴い産婦の不安が増強する ことが, STAIの状態不安尺度や血漿アドレナ リンの測定結果から指摘されている ${ }^{9) 10) . ~}$

尾島11) は, 分婏におけるRelaxationの効果 として, 軟産道や関連痛の発生部位が緊張を減 じて弛緩すれば，分娩進行はスムーズとなり，
関連痛も抑制され, 産痛が減退すると主張し, さらに, Melzackらのゲートコントロール説か ら, Relaxationによる弛緩や不安の軽減は太 い神経によるゲート閉鎖に有効であると説明で きるとしている。

またATは，Prillらによって分婏にも応用さ れ，痛みの顕著な緩和が観察されたと報告され ているが，この研究には対照群が設定されてい ない12).

宮本らのATを使用した分婏準備教育に関す る実態調查によると, 練習を週 3 回以上, 3 ヶ 月以上継続して実施していた者に関しては, 練 習回数が少なかった者より, 分婏時の不安や緊 張度が有意に少なかった ${ }^{13)}$ と報告されている。

螈崎ら 14) は, 分婏時に预けるRelaxationの 作用機序の解明を目的に, Microvibrationを 利用して調查し，AT等によるRelaxation 施行 例と非施行例を比較検討した. そして「Relaxation の効果は身体変化および精神的変化から自律 神経系に作用し，分婏進行に良い効果を及淁す」 と考察している.

以上より, 分婏進行に伴い産婦の不安は増強 していく傾向にあるが，分婏前にATを第 2 公 式まで習得していれば，AT使用によるRelaxation が, 産婦の状態不安を軽減しらる, さらにそれ が産痛の知覚にも影響を及ぼす，また，全身の 筋緊張が緩和し関連痛の発生が抑制できる, そ れらの相乗効果によって産痛緩和が促進される と仮定できる。 
そこで, 本研究では, 分婏準備教育プログラ ムの一構成要素であるRelaxationの技法に関 してATを教授し, ATによるRelaxationの産婦 の不安の軽減と産痛の緩和に対する効果を検証 することを目的とした。

\section{II. 研究方法}

\section{1. 研究対象}

1988年 4 月から 9 月末で, 東京都内の K 産院 にて実施した。研究対象者は, 医学的リスクが なくかつ研究参加の承諾の得られた妊産婦とし た、束ず，ATを教授するクラスの参加募集を 行い, 1 コース 6 回にて開催した. クラスでは, ATの創始者Schulz とLuthe ${ }^{15)}$ の方法に基づき， 佐々木の方法 ${ }^{16)}$ に準じて，ATの標準練習の第 2 公式までを段階的に教授したＡTの練習に は, 佐々木雄二指導・吹き込久による創元社発 行の「自律訓練法の実際」のテープを使用した. 研究者は, クラスの指導には直接関わらなかっ た。

分婏時のATの応用が可能であると考穴られ る，表 1 に示した(1)〜(4)の条件すべてを満たし た者を本研究での自律訓練法習得群とした。自 律訓練法習得群以外のクラス参加者を自律訓練 法未習得群とし，両群を合わせて自律訓練法訓 練群とした・ATを習った経験がなく，自律訓 練法訓練群と同一時期に分婏のために入院した

\section{表 1 自律訓練法習得群の条件}

＊以下の 4 条件すべてをみたしていること

(1)ATの練習を毎日または 1 日招き $1 \sim 2$ 回/日 以上の割合で行っている者

(2)ATの練習を 8 週間以上継続していたと報告 した者

(3)重感・温感が感じられたと報告していること

(4)ATの練習中に筋肉の弛緩が客観的に確認さ れたこと
者で, 妊娠経過が正常で分婏も正常に経過しそ らな初産婦に研究参加を依頼し, 承諾の得られ た者を自律訓練法未訓練群とした(各々, 習得 群, 未習得群, 訓練群, 未訓練群と略す).

\section{2. 分婏経過中の調査について}

表 2 のように，子宮口の開大度で分婏時期を 区別し，データを比較するために，パルトグラ ムや担当助産婦の意見を参考に，子宮口の開大 度の他, 陣痛周期や肛門圧迫感・怒責感の有無 等の基準に準じて各調查時期を選定した。調査 協力の確認をした後, 原則として 1 回の調查時 間の目安を20分間とし, 研究対象者のベットサ イドにて調査を行った. 調査協力不可能と判断 された場合は，分婏終了後にその時の気持ち・ 産痛を想起してもらい，評価する方法を用いた。 原則として，客観的評価のためのチェック以外 には，産婦に対してRelaxationを誘導するよ らな援助は行わなかった。

\section{3. 分婏時の測定用具}

\section{1 ) 不安の測定用具}

産婦の不安の測定には, Spielberger ${ }^{17)}$ が考 案した状態不安尺度の中里ら ${ }^{18)}$ の日本語版を 用いた。分婏といら状沉を考慮して，佐野ら ${ }^{10)}$ 之同様に10項目を選択し，40点満点とした。 （佐野らのプレテスト20例において，20項目と10 項目の相関係数は，0.990と報告されている; 間隔尺度）

\section{2 ) 産痛の測定用具}

Relaxationの効果として, 不安の軽減や緊 張緩和に伴って現れると考光られる産痛の知覚 の状態をみるために，対象者の産痛を主観的・ 客観的に測定した。産痛の主観的評価の強度に ついては0 to 100 Numeric Scale (NSと略す； 比率尺度)で，その質についてはMcGill Pain Questionnare (MPQと略す；間隔尺度)で測定

表 2 分婏各期の名称

\begin{tabular}{|c|c|c|c|c|c|c|}
\hline \multirow{2}{*}{ 本研究での名称 } & \multicolumn{3}{|c|}{ 分 婏 第 1 期 } & \multicolumn{2}{|c|}{ 分 婏第 2 期 } & \multirow{2}{*}{ 分婏第 4 期 } \\
\hline & 準備期 & 進行期 & 極 & 娩出期前期 & 婏出期後期 & \\
\hline 子宮口開大度 & $0 \mathrm{~cm} \sim$ & $4 \mathrm{~cm} \sim$ & $7 \mathrm{~cm} \sim$ & $10 \mathrm{~cm}$ & $\begin{array}{c}\text { 胎児婏出前 } \\
20 \text { 分 }\end{array}$ & $\begin{array}{c}\text { 胎盤婏出後 } \\
30 \sim 60 \text { 分 }\end{array}$ \\
\hline
\end{tabular}


した. 両用具ともに, 臨床的痛みの測定用具で, 信頼性・感受性が認められている ${ }^{19)}$. $\mathrm{MPQ}^{20)}$ は, 欧米では信頼性・妥当性の検証がなされて いるが，日本語訳については検証されていない。 しかし，プレテストでも，選択された言葉に固 有の傾向があり, 分婏の時期に対応して, 痛及 の得点が増加したので, 群間の痛みの質の差を 測定する用具として使用した。客観的評価には， 加納ら 21)の研究と同様に, 飛松ら 22)の産婦ス コアー(序数尺度)を用いた。これは産婦に対す る減痛方法の効果を $10 \sim 20$ 例を 1 群として比較 するために開発されたものである.

3 ) 血圧・脈拍数の測定

分婏経過に伴ら不安や産婦に対する生体反応 と，それに拮抗するRelaxationの技法による 弛緩反応 (Relaxation 効果)の双方の生理学的 反応として，分婏第 1 期中に，血圧と脈拍数を 測定した.これは先の調査と同一時期に研究者 が行った. 血圧と脈拍数の測定には, オシオメ トトリック方式の自動血圧計を使用し, 陣痛発 作中, 陣痛終了直後, 陣痛間歇時(陣痛終了後 30 秒後)に, 2 回ずつ測定した(陣痛中・陣痛直後・ 間歇時之略す).

4) 神経筋コントロール力評価スケール23)

神経筋コントロール力を「子宮収縮に対して 反応する際に, 随意的な骨格筋の弛緩を引出し 維持する能力」 23) と定義した。これを評価す ることは, 分婏時の筋緊張の緩和の維持状態を 測定することであると考光た．研究者がBernardini ら23)の作成した神経筋コントロール力の基準 を日本語訳し, 点数評価がしやすいようにその 項目に解釈を付け加えた評価スケールを用いて 評価し, その総得点をBernardini ら 23)の判定 基準 ( 5 段階) に従い分類し, 神経筋コントロー ル力を判定した (序数尺度).

5 ) ラマーズ法評価用具

$\mathrm{K}$ 産院の陣痛室・分婏室では, 助産婦の指導 に従って, 産婦はラマーズ法の実施を試みてい る. 不安感や産痛を強く訴光る症例においては, ラマーズ法の実施が困難となることはよく報告 されている.ATのRelaxation効果として, 不 安が軽減されるならば, 分婏時のラマーズ法の 実施は容易となると考える。ATの効果を産婦
の行動面から評価するために, 加納ら 21$)$ 作成 のラマーズ法評価用具を使用した(間隔尺度).

得点が高い汪ど，ラマーズ法の実施が困難であ ることを示すようになっている.

なお，分婏時の測定用具については，10人の 対象について. $1 \sim 3$ 回のプレテストを行い, 臨床助産婦等の意見を加味し, 可能な範囲で妥 当性と信頼性を確認し，一部修正して用いた。

6 ）分婏時の測定項目に影響を及ぼす要因

分婏時の測定項目に影響すると考兄られる対 象の要因についても情報収集を行った。また， 分婏経過中に異常が診断されたものは，その時 点からその対象の測定值を分析データとしなかっ た。

結果の分析には統計学的方法を用い, 各項目 の測定値を習得群, 未習得群, 未訓練群におい て比較した. 有意差検定には, $\mathrm{x}^{2}$ 検定 (序数尺 度), $\mathrm{t}$ 検定と $\mathrm{F}$ 検定 (間隔尺度 - 比率尺度)を 用い，有意水準は $1 \%$ としたが，5\%を有意な 傾向と解釈した.

\section{III. 研究結果}

\section{1. 研究対象者について}

対象者は, 習得群11名 (平均年歯28.6 2 2.7歳), 未習得群 21 名 ( $28.2 \pm 2.3$ 歳), 未訓練群 12 名 $(25.7$ \pm 3.0 歳)の合計 44 名であった. 訓練群は未訓練 群より有意に高齢であった $(\mathrm{t}$ 検定, $\mathrm{p}<0.01)$. 初経産の割合には有意差はなかった(表 3 ).

月経痛の程度・痛久に対する感受性の自己評 価・手術歷の有無・分婏に関する知識・他の分 娩準備教育の受講 (表 4 ) ・呼吸法やAT以外の Relaxationの技法の練習に拈いて，3群間に 有意差はなかった。妊娠中の血圧は, 妊娠後期 の妊婦健診時の血圧值 3 回をそのデータとした が， 3 群間に有意差はなかった。

表 3 研究対象者の内訳

\begin{tabular}{c|c|c|c}
\hline 初 経 産 & 習 得 群 & 未習得群 & 未訓練群 \\
\hline 初 産 婦 & 10 & 19 & 12 \\
1 回経産婦 & 1 & 2 & 0 \\
合 計 & 11 & 21 & 12 \\
\hline \multicolumn{4}{|c|}{$\mathrm{p}>0.1\left(\mathrm{x}^{2}\right.$ 検定 $)$}
\end{tabular}


表 4 他の分婏準備教育の受講

\begin{tabular}{|c|c|c|c|c|}
\hline & & 習 得 群 & 未習得群 & 未訓練群 \\
\hline 有 & $\eta$ & 7 & 11 & 3 \\
\hline 無 & L & 4 & 10 & 9 \\
\hline
\end{tabular}

\section{2. 不安について}

妊娠中の合併症・特性不安・妊娠中の心理社 会的因子等，分婏時の不安に影響すると考㝋ら れる因子において，3 群間に有意差はなかった。

未習得群と未訓練群では, 極期の状態不安得 点は各々, 進行期のそれらよりも有意に増加し ていた $(\mathrm{p}<0.01)$ 。それに対して習得群では， 進行期と極期の平均得点はあ屯り变わらず，他 の 2 群より低值を示した。 さらに，極期・婏出 期前期・婏出期後期では, 習得群の状態不安得 点が，他の 2 群より有意に低かった $(\mathrm{p}<0.01$, 表 5 ).

\section{3. 産痛の主観的・客観的評価}

産痛の強度を表すNSの平均得点は，どの群 に扮いても，準備期に比べて進行期，進行期に 比べて極期で有意に $(\mathrm{p}<0.01)$ 高得点を示し， 婏出期には減少していた。進行期においてのみ，

表 5 群別の状態不安得点

\begin{tabular}{|c|c|c|c|c|}
\hline \multicolumn{2}{|l|}{ 分 婏 期 } & 習 得 群 & 未習得群 & 未訓練群 \\
\hline \multirow{3}{*}{ 準備期 } & 平均 & 18.5 & 22.4 & 22.0 \\
\hline & S D & 6.5 & 5.7 & 3.9 \\
\hline & $\mathrm{n}$ & 2 & 13 & 7 \\
\hline \multirow{3}{*}{ 進行期 } & 平均 & 23.5 & 25.3 & 25.3 \\
\hline & S D & 4.9 & 5.2 & 2.3 \\
\hline & $\mathrm{n}$ & 8 & 14 & 9 \\
\hline \multirow{3}{*}{ 極 期** } & 平均 & 24.1 & 29.9 & 32.6 \\
\hline & S D & 3.5 & 6.3 & 3.0 \\
\hline & $\mathrm{n}$ & 7 & 15 & 10 \\
\hline \multirow{3}{*}{$\begin{array}{l}\text { 婏出期** } \\
\text { 前 期 }\end{array}$} & 平均 & 20.0 & 29.9 & 31.0 \\
\hline & S D & 6.0 & 4.1 & 1.1 \\
\hline & $\mathrm{n}$ & 5 & 7 & 8 \\
\hline \multirow{3}{*}{$\begin{array}{l}\text { 婏出期** } \\
\text { 後 期 }\end{array}$} & 平均 & 20.5 & 30.5 & 30.3 \\
\hline & S D & 5.0 & 7.1 & 3.7 \\
\hline & $\mathrm{n}$ & 8 & 11 & 9 \\
\hline \multirow{3}{*}{$\begin{array}{l}\text { 分 婏 } \\
\text { 第 } 4 \text { 期 }\end{array}$} & 平均 & 14.9 & 17.2 & 16.4 \\
\hline & S D & 3.3 & 3.1 & 4.3 \\
\hline & $\mathrm{n}$ & 10 & 16 & 12 \\
\hline
\end{tabular}

3 群間に有意な傾向がみられた $(\mathrm{p}<0.05$, 表 6 ).

産婦の質を表すMPQは，総得点が高いほど， 痛みが質的に強いことを示す，MPQに招いて も，NSでピークとなった極期で，すべての群 の得点が高くなった。 また，分婏第 1 期の産痛 の客観的評価においても同様であった.

MPQの測定結果を 3 群間で比較した結果, 極期のMPQの感覚的評価指数でのみ, 習得群 の得点が他の 2 群に比べて，有意に低かった (p<0.001，表 7 ).

極期の客観的評価に抒いては，3 群間に有意 差はみられなかったが，習得群の 7 人中 6 人が 良束たは可であった（ $\mathrm{x}^{2}$ 検定 $\mathrm{p}>0.1 ）$

\section{4. 分婏第 1 期の血圧亡脈拍数}

未習得群と未訓練群では, 分婏の進行に伴い, 血圧の平均值は，漸次，上昇傾向を示したが， 有意差はなかった。習得群では, 進行期と極期

表 6 群別のNSによる産痛の主観的評価

\begin{tabular}{|c|c|c|c|c|}
\hline & & 習 得 群 & 未習得群 & 未訓練群 \\
\hline \multirow{3}{*}{ 準備期 } & 平均 & 45.0 & 53.8 & 61.4 \\
\hline & S D & 22.9 & 10.4 & 12.2 \\
\hline & $\mathrm{n}$ & 4 & 13 & 7 \\
\hline \multirow{3}{*}{ 進行期* } & 平均 & 59.4 & 75.7 & 74.4 \\
\hline & S D & 11.8 & 14.6 & 10.4 \\
\hline & $\mathrm{n}$ & 8 & 14 & 9 \\
\hline \multirow{3}{*}{ 極 期 } & 平均 & 81.4 & 83.3 & 92.0 \\
\hline & S D & 8.3 & 17.3 & 10.3 \\
\hline & $\mathrm{n}$ & 7 & 15 & 10 \\
\hline \multirow{3}{*}{$\begin{array}{l}\text { 婏出期 } \\
\text { 前 期 }\end{array}$} & 平均 & 79.0 & 75.0 & 89.4 \\
\hline & S D & 12.0 & 30.1 & 11.8 \\
\hline & $\mathrm{n}$ & 5 & 7 & 8 \\
\hline \multirow{3}{*}{$\begin{array}{l}\text { 娩出期 } \\
\text { 後 期 }\end{array}$} & 平均 & 60.6 & 70.9 & 80.6 \\
\hline & S D & 24.6 & 29.4 & 13.8 \\
\hline & $\mathrm{n}$ & 8 & 11 & 9 \\
\hline
\end{tabular}

表 7 極期における群別のMPQ

\begin{tabular}{|c|c|c|c|c|}
\hline & & $\begin{array}{l}\text { 習 得 群 } \\
(\mathrm{n}=7)\end{array}$ & $\begin{array}{l}\text { 未習得群 } \\
(\mathrm{n}=15)\end{array}$ & $\begin{array}{l}\text { 未訓練群 } \\
(\mathrm{n}=9)\end{array}$ \\
\hline 感覚的 & 平均 & 13.0 & 20.9 & 18.7 \\
\hline 指数 $* * *$ & S D & 2.3 & 4.9 & 2.7 \\
\hline 感情的 & 平均 & 8.5 & 11.3 & 11.0 \\
\hline 指数 & S D & 4.3 & 5.0 & 3.5 \\
\hline
\end{tabular}


の血圧値の平均値の差はあまりなく, 有意差は なかった(図 1).3群における分散分析の結果, 有意な傾向がみられたのは, 極期の陣痛直後の 収縮期血圧值のみであった。この極期と妊娠後 期の血圧値を比較したところ, 未訓練群・未習 得群では, 極期すべての時期で $10 \sim 20 \mathrm{mmHg}$ 位の差が有意に $(\mathrm{p} く 0.01)$ みられた。しかし， 習得群の陣痛直後や間歇時の収縮期血圧は, 妊 娠後期に比べて $5 \mathrm{mmHg}$ 未満の差しかなく, 有意差もなかった(表 8 ).

脈拍数の平均值も未訓練群・未習得群では, 分婏経過に対応して, 漸次上昇傾向にあったが, 有意差はなかった。習得群では, 進行期と極期 の脈拍数の平均値は他の 2 群ほどの差はみられ ず，有意差もなかった。極期において，陣痛中 の脈拍数の分散分析の結果, 3 群間で有意な傾 向が認められた(習得群 : $\bar{x}=84.6 \pm 12.3$ 未 習得群 : $\overline{\mathrm{x}}=82.3 \pm 16.8$ 未訓練群 : $\overline{\mathrm{x}}=98.9$ $\pm 8.7 \mathrm{p}\langle 0.05$, 図 2$)$.

\section{5. 神経筋コントロールカの判定結果}

神経筋コントロール力の評価判定結果を 3 群 間で比較した結果, 極期に扔いて, 有意差がみ
られた。（ $\mathrm{x}^{2}$ 検定 $\mathrm{p}<0.01$, 図 3 )

\section{6. ラマーズ法評価得点}

進行期・極期では, 習得群が他の 2 群に比べ て，ラマーズ法の実施において優れていたとい ら有意な傾向がみられた。（p<0.05, 表 9 )

\section{7. 分婏時の状況の群間比較}

分婏㥞式, 分婏時の異常, 分婏時妊娠週数, 陣痛の種類, 羊水混濁の有無, 分娩所要時間, Apgar Score, 分婏各期の調査時の陣痛発作時 間之陣痛間歇時間, 1 回調查時間等の分婏時の 状況において，3群間に有意差はなかった。

\section{IV. 考察}

分婏準備教育の効果は，分婏時の鎮痛剂・鎮 静剂の使用量や産婦の態度の客観的評価などを 指標として実証されてきた2425)26)。 また，分 娩準備教育受講の前後で妊婦の不安を測定しそ の効果を論じたもの 26)27) や，産裖期の調査や 面接によって, 産痛や分婏体験について検討し たもの 28)29)が多い。それに対して，産婦の不
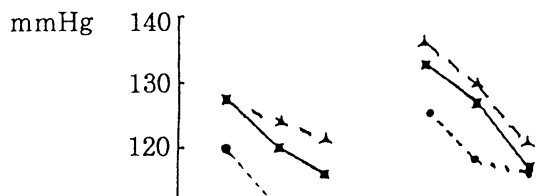

110
100
90
80
70
60 60
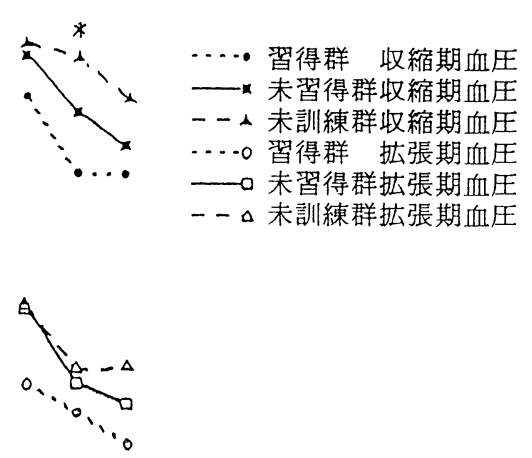

$* \mathrm{P}<.05$
準備期 進行期 極 期 分姢経過

習得群 $\mathrm{n}=2 \quad \mathrm{n}=15 \quad \mathrm{n}=11$

未習得群 $\mathrm{n}=26 \quad \mathrm{n}=28 \quad \mathrm{n}=25$

未訓練群 $\quad \mathrm{n}=14 \quad \mathrm{n}=15 \quad \mathrm{n}=17$

\section{図 1 群別の分婏第 1 期の血圧}


表 8 妊娠後期と極期の血圧

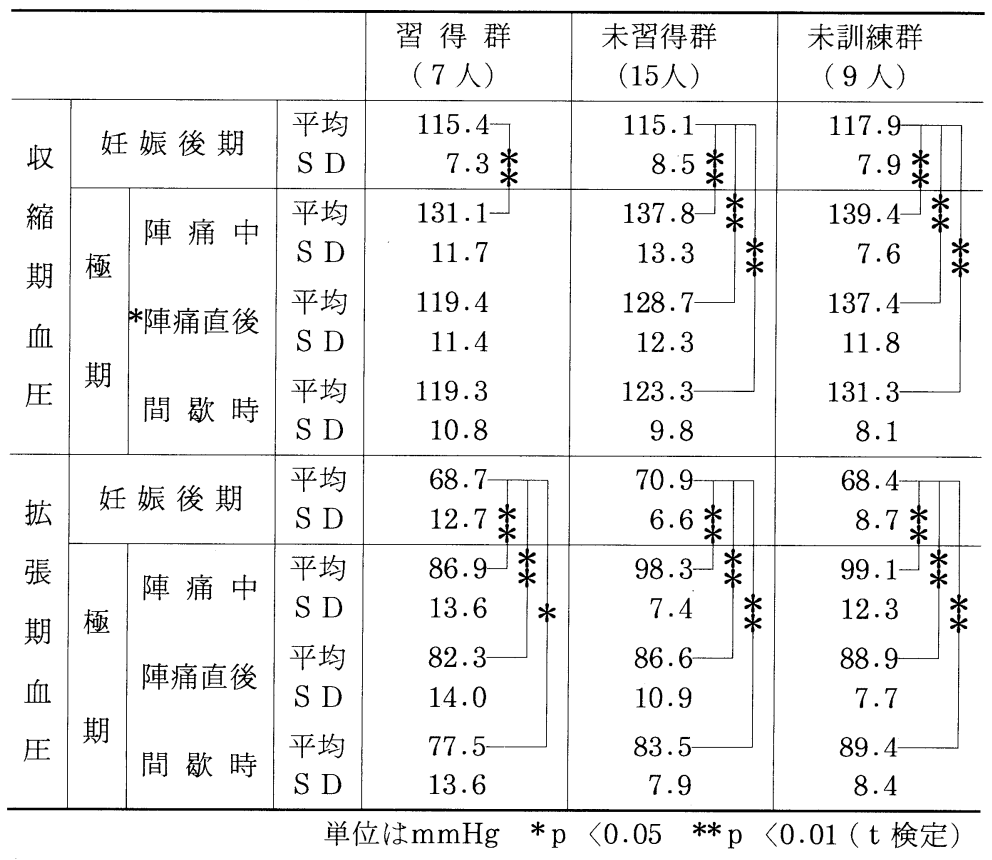

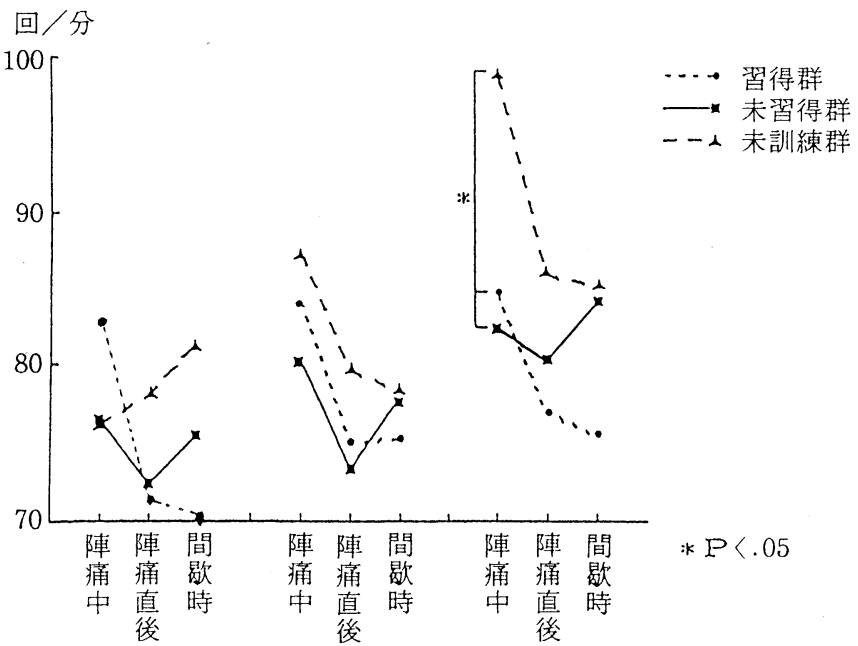

準備期 進行期 極 期 分娩経過

習得群 $\mathrm{n}=2 \quad \mathrm{n}=15 \quad \mathrm{n}=11$

未習得群 $n=26 \quad n=28 \quad n=25$

未訓練群 $\quad \mathrm{n}=14 \quad \mathrm{n}=15 \quad \mathrm{n}=17$

図 2 群別分婏第 1 期の脈拍数 


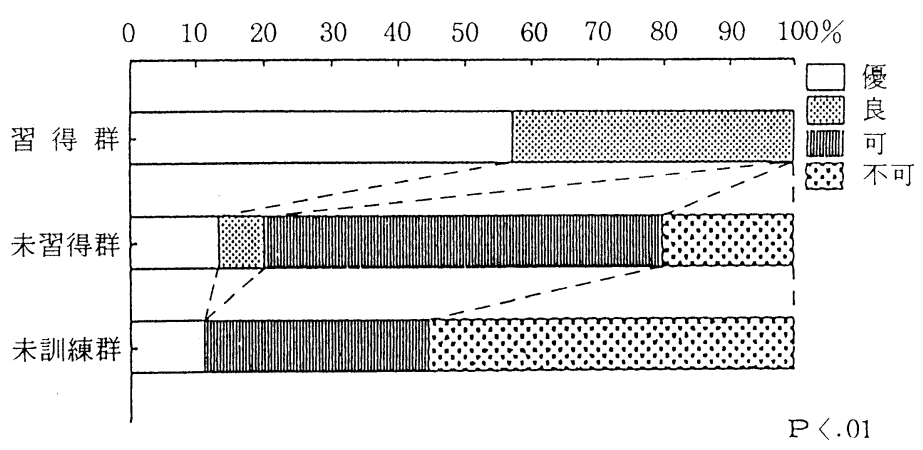

図 3 極期の神経筋コントロール力評価判定結果

表 9 群別のラマーズ法評価得点

\begin{tabular}{|c|c|c|c|c|}
\hline & & 習 得 群 & 未習得群 & 未訓練群 \\
\hline \multirow{3}{*}{ 準備期 } & 平均 & 1.0 & 1.0 & 1.3 \\
\hline & S D & 0.0 & 1.0 & 1.6 \\
\hline & $\mathrm{n}$ & 1 & 13 & 7 \\
\hline \multirow{3}{*}{ 進行期* } & 平均 & 0.9 & 2.5 & 2.0 \\
\hline & S D & 0.9 & 1.2 & 1.4 \\
\hline & $\mathrm{n}$ & 8 & 14 & 9 \\
\hline \multirow{3}{*}{ 極 期* } & 平均 & 1.3 & 3.5 & 4.0 \\
\hline & S D & 1.0 & 2.0 & 1.7 \\
\hline & $\mathrm{n}$ & 7 & 15 & 9 \\
\hline \multirow{3}{*}{$\begin{array}{l}\text { 婏出期 } \\
\text { 前 期 }\end{array}$} & 平均 & 2.0 & 2.5 & 2.9 \\
\hline & S D & 1.7 & 1.5 & 1.1 \\
\hline & $\mathrm{n}$ & 5 & 7 & 8 \\
\hline \multirow{3}{*}{$\begin{array}{l}\text { 婏出期 } \\
\text { 後 期 }\end{array}$} & 平均 & 1.5 & 1.9 & 2.1 \\
\hline & S D & 1.7 & 1.2 & 0.7 \\
\hline & $\mathrm{n}$ & 8 & 11 & 9 \\
\hline
\end{tabular}

安や産痛の知覚を分婏時に測定し，その効果を 検討した研究は少ない，さらに，そのプログラ ムの構成要素の各々についても分婏時の効果が 検証されていない。

一方，ATは，分婏準備教育の構成要素であ るRelaxationの技法の一つであり，分娩環境 以外で臨床応用され，そのRelaxationの効果 が不安の軽減やそれに伴ら痛みの緩和について 報告されているが，産婦の不安の軽減や産痛の 緩和のために，分婏時にRelaxationの効果を 検証した研究はみあたらなかった。

\section{1. 対象について}

ATを教授するクラスでは，研究施設の分婏 準備教室で提供されている情報量を越えないよ
うに配慮した。また，分婏に関する知識やこの クラス以外の分婏準備教育クラスへの参加に関 して，3 群間に有意差はなかった。 Bernardini ら23)の分婏時の神経筋コントロール力に好影 響するとした練習基準を満たした対象は，1〜 2 名以下と少なく注涪同率であった。研究施設 では，夫の立ち会い分婏を取り扱っていない。 従って，3 群を比較する際に他の構成要素の効 果を考虑せずに検討できると考える.

\section{2. 分婏時のRelaxation 効果}

1 ) 不安の軽減

研究対象者は, 研究施設のルチーンの看護を 受けていた。また，研究者の調査時間は一定に なるように試み， 3 群間で有意差はみられなかっ た。それゆえ，産婦の不安に対するRelaxation 効果を状態不安を指標に，3 群間で比較するこ とができるとした。

分婏第 1 期の終わりである極期は，林らの産 後調査 ${ }^{30)}$ で最も不安であったと報告された時 期であり, 加納ら 21)の研究では対照群の状態 不安得点のピークでもあった。本研究の未習得 群や未訓練群の状態不安は, その極期で進行期 より有意に高く，それがほぼ分娩第 2 期丈で持 続していた。これは，佐野ら 10)・新道ら ${ }^{31)}$ ・

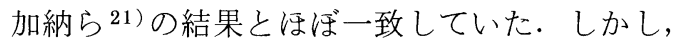
習得群の状態不安は, 極期では進行期とあまり 変わらず，かつ他の 2 群に比べて有意に低く， 分婏第 2 期に扔いても他の 2 群より有意に低い 得点を維持していた。本研究でも, 加納ら 21) の研究と同様に極期には, 産婦の多くは陣痛室 におり, 研究施設では, 陣痛室内で看護者が産 
婦に持続的に付き添う看護はルーチンにはなっ ていなかった，分婏室に入室するのは，通常， 分婏第 2 期になってからであり，怒責を加える ことが指導され，それによって産婦にも分婏の 予測が可能となる. 習得群は, 他の 2 群に比べ て不安が少なかったため, 分婏第 2 期になって 先の見通しを実感し，より不安が軽減されたと 思われる.以上のことから, 習得群はATによ るRelaxation 効果により分婏進行に伴ら状態 不安の増強を抑制できたと考える。

2 ) 産婦の緩和(不安や筋緊張等々の関係から)

$\mathrm{K}$ 産院では分娩遷延の適応でのみ陣痛促進剂 が使用され，3群間に陣痛促進剂使用の差はみ られず，子宮口全開大以前に人工破膜を受けた 対象はいなかった。加えて, 分婏時の痛みの知 覚に影響する他の因子についても 3 群間で有意 差がなかったので, 産痛の主観的評価を 3 群間 で比較することができるとした。

進行期では, 習得群の産痛の強度を示す NS とラマーズ法評価得点はともに，他の 2 群のそ れらより各々低い傾向がみられた。 3 群の状態 不安に有意差はなかったが, 習得群のそれは最 も低かったささらにこの時期の状態不安や神経 筋コントロール力判定結果とNSとの間には, 有意な相関関係があった（ $\mathrm{r}=0.35 \mathrm{p}<0.05$ ， $\mathrm{r}=0.53 \mathrm{p}<0.01)$. 低い状態不安と良好な 神経筋コントロール力の相乗効果のため, 習得 群は他の 2 群より産痛の強度が緩和され, ラマー ズ法の実施状態も良好であったと推察される. この結果は, Cogan 5 ${ }^{32)}$ が指摘した分婏第 1 期初期の産痛の強度と分姢準備の達成による自 信の相関関係を支持するものであったと考兄ら れる. 分婏がさらに進行した極期では, 習得群 は他の 2 群に比べて, 痛みの感覚的側面でも, Melzack ら $\left.{ }^{33}\right)$ の研究成果と同様に産痛を有意 に低く報告していた。この極期において, 習得 群は他の 2 群に比べて, 状態不安が有意に低く, 神経筋コントロール力も有意に良好であった. さらに習得群に拀いてのみ, 状態不安と神経筋 コントロール力判定結果に, 強い相関関係が有 意な傾向であった $(\mathrm{r}=.78 \mathrm{p}<0.05)$. 以上 のことを考光合わせると, 習得群は他の 2 群よ り状態不安が低く, 神経筋コントロール力も良
好に維持され，それらの相乗効果のため，産痛 の質的な知覚においても他の 2 群との違いが現 れたと思われる。また，ラマーズ法評価得点の 結果にもその違いが認められた。これは, 従来 の分婏準備教育の研究成果 ${ }^{26)}$ を支持するもの であった。

\section{3 ) 血圧亡脈拍数}

Bonica $^{34)}$ は分娩第 1 期中の血液循環器系の 変化の原因として, (1)子宮収縮, (2)疼痛と不安, (3)産婦の体位, (4)自主的な活動, (5)酸素の消費, (6)合併症をあげ，これらが心拍数を上昇させ， 一回拍出量を増加させているとしている。研究 対象者には, 循環器系に影響するような合併症 をもった者や，妊娠中の脈拍や血圧にも異常が 指摘された者や，分婏時の体位や行動において 特異な者はいなかった。 そこで， 3 群間で疼痛 と不安以外の上記因子について差はなかったと 仮定して，検討することにする．不安との相関 関係があるカテコールアミンを出産間近い赤毛 ザルに静脈注射するといら実験 ${ }^{35}$ ) や, 恐怖(不 安) 時の生体反応 ${ }^{213)}$ 上り, 産婦の不安の増強 は，血圧と心拍数を上昇させると考えた。 また， 陣痛発作時には, 子宮収縮により血圧と心拍数 は上昇するが，陣痛終了とともに十分にRelaxation できれば，それらがすぐに弛緩反応により平 常値に戻ると予想されたので, 陣痛中・陣痛直 後・間歇時の 3 回に分けて測定した.

状態不安において 3 群間に有意差のみられた 極期では, 習得群の陣痛間歇期 (陣痛直後と間 歇時)の血圧が，妊娠中のそれと比べて差がな く, 变動が少ない傾向が伺われた。 また, 習得 群の進行期と極期の血圧と脈拍数は, 有意差は なかったが，他の 2 群のそれらに比べて各々低 い傾向にあった. 習得群の血圧と脈拍数の平均 值は, Robson ${ }^{36)}$ が妊娠中と分娩時に継続的に 測定した心拍数・平均血圧の結果に近似してい た.この研究対象者は吸入麻酔を受けていたた め，佐野ら 10)の報告した硬膜外麻酔をうけて いた症例において, 不安が軽減していたように, 不安や産痛が軽減されていたと思われる. 従っ て, 習得群の結果は, Relaxation 効果によっ て不安や産痛が軽減されていたことを支持する ものであると推察される. 


\section{V. 結 論}

1. 結 論

1）分娩進行に伴ら不安の増強が，自律訓練法 習得群では，他の 2 群よりも抑制された。

2 ) 産痛の主観的評価は，自律訓練法習得群で は他の 2 群より, 進行期の産痛の強度は緩和 され，極期の産痛の感覚的評価指数は有意に 低い值を示した。

3 ）極期の陣痛間歇期の血圧と脈拍数の平均值 は，自律訓練法習得群が他の 2 群のそれらに 比べて低かったが，有意差はなかった。

4 ）神経筋コントロール力は，自律訓練法習得 群では，他の 2 群より有意に良好な結果を示 した.

5 ）ラマーズ法評価得点は, 自律訓練法習得群 では，他の 2 群より進行期・極期においてそ の実施が優れているといら有意な傾向がみら れた。

以上により, 産婦の不安の軽減や産痛の緩和 のために，分婏前からの看護の方法として，

Relaxationの技法を教授することは，分婏時 のRelaxation 効果を促し，産婦の不安の軽減 や産痛の緩和に対し有効であることが明らかに なった。

\section{2. 研究の限界と課題}

臨床における研究であったため，条件を厳密 に調整することが困難であった。AT教授クラ スへの参加は任意であったため, 研究対象者を 無作為にふりわけることはできなかったので， 訓練群はクラス参加への動機をもっているとい ら対象特性があることはさけられないことであ る.未習得群と未訓練群が極期以降の測定值で 近似した傾向を示したことから，中途半端な教 育では，しない場合と大差がないとも考兄られ， 効果的な教授方法を検討する必要性が示唆され た。また，仮に未習得群 21 人すべてが脱落例と すると，ATを習得しやすい対象特性が習得群 にあったかもしれないといらことも考兄られる。 このことは，現段階では臨床における研究の限 界であり，このような対象特性について追求す ることも，今後の課題であると考える.
謝辞

本研究にご理解とご協力をいただきました産 院の職員の皆様, 本研究に快くご協力ください ました妊産婦の方々や，千葉大学母性看護学講 座の教員および大学院生に深謝いたします。

（尚，本論文の要旨は，第 9 回日本看護科学学 会において発表した.)

\section{引用文献}

1) Benson, H., Beary, J.F. and Carol, M.P.: The Relaxation Response, Psychiatry, 37, 37-46, 1974

2 ) 高橋宏: 心拍と呼吸, 現代精神医学体系 $20 \mathrm{c}$ 神経生理学 III, 中山書店, 65-66, 1978.

3 ) Ax, A.F.: The Physiological Differentiation between Fear and Anger in Humans, Psychosom . Med., 15, 433, 1953.

4 ）内山喜久雄 : サイコセラピーシリーズ行動療 法，文光堂，71-79，1972.

5 ） W.ルーテ編, 池見西次郎監修, 内山喜久雄 訳：自律訓練法第 I 巻，誠信書房，4-7, 1971.

6 ）桂戴作, 他：自律訓練法, 催眠療法, 心身医, 22 (5) $412-417,1982$.

7 ) 成田則正, 他：心身症患者に対する自律訓練 法の効果，心身医，21(3)，201-206，1981.

8 ）石岡昭，他：心身症患者の治療前後における STAI とEgogram の推移，心身医，22(4)， 338-342, 1982.

9 ) Lederman, R.P., et al.: The Relationship of Maternal Anxiety Plasma Catecholamines and Plasma Cortisol to Progress in Labor, Am . J.O.G. , 132, 495-500, 1978.

10）佐野敬夫，他：分婏中及び分婏後に打ける血 中カテコールアミンの動態に関する研究，心 身医, 24(5), 1984 .

11）尾島信夫，他：ラマーズ法の基本の再構築と 強化, これからのラマーズ法, メディカ出版, 86-89, 1986.

12) Luthe, W., Schulz, J.H.: 10. Pregnancy and Birth, In Autogenic Therapy II , 149-154, Grune \& Stratton Inc., New York, 1969.

13）宮本僼子，他：母親学級におりる自律訓練法 の実態調査について，母性衛生，25(2)， 244-247, 1984.

14）蠣崎和彦，郷久鋮二：分婏第 1 期のMicrovibration，産科之婦人科，49，38-43，1982. 
15）前掲書 5) 24-137.

16）佐々木雄二：自律訓練法の実際一心身の健康 のために一，創元社，1976.

17) Spielberger, C.D. , Gorsuch, R.L. , \& Lushene, R.E. : Manual for the State-Trait Anxiety Inventory (Self-evaluation Questionnare), Consulting Psychologists Press, 2-24, Palo Alto, Calif., 1970.

18）中里克治, 水口公信: 新しい不安尺度STAI. 日本版の作成，心身医，22(2)，108-112，1982.

19) Stewart, M.L.: Measurement of Clinical Pain, In Pain-A Source Book for Nurses and Other Health Professionals, edited by Jacox, K.A. , 107-113, 1977.

20) Melzack, R.: The McGill Pain Questionnaire; Major Properties and Scoring Methods, Pain, 1, 277-299, 1975.

21）加納尚美, 前原澄子：産婦の不安を軽減する ための看護の方法に関する研究，日本看護科 学会, $10(2), 18-27,1990$.

22）飛松源治，他：針麻酔減痛分娩，産科之婦人 科, 47(12), 18-28, 1962 .

23) Bernardini, J.Y., et al: Neuromuscular Control of Childbirth-Prepared Women during the First Stage of Labor, JOGNN, March/ April, 105-111, 1983.

24) Enkin, M.W., et al. : An Adequately Controlled Study of Effectiveness of P.P.M. Training, In Psychosomatic Medicine in Obstetrics and Gynecology 3rd int. Congr. London 1971, 62-67, edited by Morris, N., New York, Karger Basel, 1972.

25) Timm, M.M. : Prenatal Education Evaluation, NR, 28(6), 338-342, 1979.

26) Kondas, O., Scetnicka, B.: Systematic Desensitization as a Method of Preparation for Childbirth, J. Beha. Ther. \& Exp. Psy chiatry, 3, 51-54, 1972.

27）二神かず子, 他：MASによる妊産婦の心理 状態の追求一第 2 報, 母性衛生, 22(2), 71-76, 1981 .

28) Doering, S.G. and Entwisle, D.R.: Preparation during Pregnancy and Ability to Cope with Labor and Delivery, Am. J. Orthopsychia t, 45(5), 825-837, 1975.

29) Willmuth, L.R.: Prepared Childbirth and the Concept of Control, JOGNN, Sept/Oct, 38-41, 1975 .

30）林満智子，他：分婏期における産婦と家族の 不安について，母性衛生，20(4)，71-74, 1981.

31）新道幸恵，近藤潤子：産婦のストレスの緩和 に対するTouchの影響, 日本看護科学会, 7(1), 29-38, 1987.

32) Cogan, R., William, H., et al. : Predictors of Pain during Prepared Childbirth, J. Psy chosomatic Reseach, 20, 523-533, 1976.

33) Melzack, R., Taenzer, P., Feldman, P., Kinch, R.A. : Labor is Still Painfull after Prepared Childbirth Training, Can. Med. Assoc. J., 125, 357-363, 1981.

34) Bonica, John. J.: Principle and Techniques of Psychoprophylatic Method, In Principles and Practice of Obstetric Analgesia and Anesthesia, Davis F.A.Co., Philadelphia, 79-86, 1967.

35) Myers, R.E. : Maternal Psychological Stress and Fetal Asphyxia ; A Study in Monky, Am.J.G., 122, 47-59, 1975.

36) Robson, S.C., et al.: Cardiac Output during Labour, British Medical J. , 295(7), 1169-1172, 1987. 